\title{
The first phylogenetic study of Kiliophora (Fungi, Anamorphic Xylariales)
}

\author{
Hidayat $I^{1}$, Harahap $I^{2}$ and Rahayu $G^{2}$ \\ ${ }^{1}$ Microbiology Division, Research Center for Biology, Indonesian Institute of Sciences (LIPI), Indonesia \\ ${ }^{2}$ Department of Biology, Faculty of Mathematics and Natural Sciences, Bogor Agricultural University (IPB), Indonesia
}

Hidayat I, Harahap I, Rahayu G 2014 - The first phylogenetic study of Kiliophora (Fungi, Anamorphic Xylariales). Mycosphere 5(1), 78-84, Doi 10.5943/mycosphere/5/1/3

\begin{abstract}
Kiliophora Kuthub. \& Nawawi (Type: K. fusispora Kuthub. \& Nawawi) was first described based on conidiophores bearing spindle-shaped conidia. Only two species have been reported worldwide, viz, K. fusispora and K. ubiensis Khutub. \& Nawawi. During the study of fungal diversity on Shorea spp. in Indonesia, we found K. ubiensis and successfully obtained pure isolate of this fungus through single spore isolation method. Since the taxonomy placement of this genus in the subphylum Pezizomycotina is unknown, phylogenetic analyses was carried out based on Internal Transcribed Spacer of ribosomal DNA sequence by using Maximum Parsimony method. The phylogenetic tree suggested that genus Kiliophora should taxonomically be placed in the family Amphisphaeriaceae (Ordo Xylariales). This report is the first finding of $K$. ubiensis from Indonesia.
\end{abstract}

Key words - Amphisphaeriaceae - ITS - Phylogenetic - Taxonomy - Xylariales

\section{Introduction}

Kiliophora Khutub. \& Nawawi (1993) (type: K. fusispora) was erected to replace the hyphomycete genus Danaea Caneva \& Rambelli (1981) (type: D. ubiensis Caneva \& Rambelli) (Kuthubutheen \& Nawawi 1993). Kuthubutheen \& Nawawi (1993) noted that the generic name of Danaea was illegitimate according to the Code article 64.1, due to its incontradiction with Danaea Sm. (1793), a tropical fern endemic to South America. The name of Kiliophora was based on conidiophores bearing spindle shaped conidia. This genus is characterised by having enteroblastic, polytretic, and discrete conidiogenous cells arising directly and from about midway up the setiform conidiophores, and acropleurogenus, hyaline-pale brown, fusiform to spindle-shaped conidia (Kuthubutheen \& Nawawi 1993). The taxonomic position of Kiliophora within Subphylum Pezizomycotina has been unknown since the first publication of this genus.

Recently, rapid progress in molecular phylogenetic analyses have resolved the taxonomy position of several uncertain fungal genera within the Kingdom Fungi. During the study of decaying wood and leaf litter of Shorea spp. in Bogor (West Java, Indonesia), we found hyphomycete specimen which morphologically resembles characteristics of K. ubiensis. Single spore isolation was successfully done to obtain the pure culture of this specimen, and therefore, the molecular phylogenetic analyses based on ITS (Internal Transcribed Spacer) rDNA sequence was carried out to examine the phylogenetic position of Kiliophora within the Subphylum Pezizomycotina. 


\section{Materials \& Methods}

\section{Morphological examination}

Specimen of K. ubiensis on leaf litter of Shorea spp. was collected from research forest area managed by the Center for International Forestry Research (CIFOR), located at the Situ Gede village, Bogor, West Java, Indonesia. The presence of fungal fruiting structures on leaf litter of Shorea spp. was examined by dissecting microscope (Olympus ${ }^{\circledR}$ SZX7, Japan). Compound microscope (Olympus ${ }^{\circledR}$ CX41, Japan) was used to determine microscopic structures. Materials were mounted in water for microscopic examination, measurement of the structures, and for photographing. Shear's solution (Kirk et al. 2008) was used for permanent fixation. 30 conidia, 10 conidiogenous cells, and 10 conidiophores were measured. Species identification was carried out based on Seifert et al. (2011). Single conidia isolation was carried out using Water Agar (WA) according to the method described by Choi et al. (1999) with certain modification. Herbarium specimen was deposited at Herbarium Bogoriense (BO), Indonesia. Culture was preserved at Bogor Agricultural University Culture Collection (IPBCC).

\section{DNA extraction, PCR (Polymerase Chain Reaction) amplification and sequencing}

A total genomic DNA was extracted from 5-days old fungal mycelia cultured in Potato Dextrose Broth (PDB) using REDExtract-N-Amp ${ }^{\mathrm{TM}}$ Seed PCR Kits (Sigma, USA), following the manufacture's protocol. Primer pairs of ITS5 (5'-GGAAGTAAAAGTCGTAACAAGG-3') and ITS4 (5'-TCCTCCGCTTATTGATATGC-3') was used for DNA amplification of ITS region, including the 5.8S rDNA region (White et al. 1990). The PCR amplification condition was performed in $25 \mu \mathrm{l}$ reaction volume as follows: nuclease free water $10 \mu 1$, GoTaq ${ }^{\circledR}$ Green Master

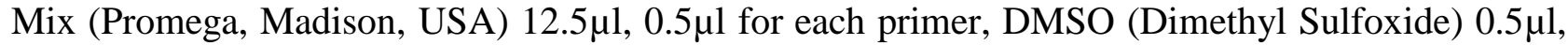
and DNA template $1 \mu 1$. PCR was performed by TaKaRa thermocycler (TaKaRa, Japan) using the following PCR parameters: initial denaturation at $95^{\circ} \mathrm{C}$ for $90 \mathrm{~s}$, followed by 35 cycles of denaturation at $95^{\circ} \mathrm{C}$ for $30 \mathrm{~s}$, annealing at $55^{\circ} \mathrm{C}$ for $30 \mathrm{~s}$, elongation at $72^{\circ} \mathrm{C}$ for $90 \mathrm{~s}$, and final extension at $72^{\circ} \mathrm{C}$ for $5 \mathrm{~min}$. The characterization of PCR product was performed via agarose gel electrophoresis on a TAE 1\% agarose gel containing Ethidium Bromide (EtBr) as the staining agent. The PCR product was sent to 1stBASE (Malaysia) for sequencing. The new ribosomal DNA sequence has been deposited in GenBank (www.ncbi.nlm.nih.gov) under accession number KF056850. The GenBank accession numbers of the other sequences and taxa used to construct the phylogenetic tree were shown in fig. 2 .

\section{Sequence alignment and phylogenetic analysis}

Sequence obtained from the respective primers (ITS5 and ITS4) was assembled and manually edited using ChromasPro 1.41 software (Technelysium Pty Ltd., South Brisbane, Australia). Dataset of Xylariales used by Jaklitsch \& Voglmayr (2012) was employed in the multiple alignment with 42 additional sequences retrieved from GenBank (NCBI, DDBJ). The multiple alignment was conducted using MUSCLE (Multiple Sequence Comparison by LogExpectation) (Edgar 2004) implemented in MEGA (Molecular Evolutionary Genetics Analysis) version 6.0 (Tamura et al. 2013). Phylogenetic analyses wasere conducted using the maximum parsimony (MP) method in PAUP* 4.0b10 (Swofford 2002). The MP analysis was performed with the heuristic search option using the 'tree-bisection-reconstruction' (TBR) algorithm with 1000 random sequence additions to find the optimum tree. The stepwise addition option set as random and maximum tree number was set at 500. Tree length (TL), consistency index (CI), retention index (RI), related consistency index (RC), and homoplasy index (HI) were also calculated. The KishinoHasegawa (KH) likelihood test (Kishino \& Hasegawa 1989) was carried out to compare the best tree topology obtained by the nucleotide sequence data with a constrained tree. The strength of the internal branches of the phylogenetic tree in MP analysis was tested with bootstrap (BS) analysis (Felsenstein 1985) using 1000 replications. BS values of $50 \%$ or higher than that are shown. Random sequence addition was used in the bootstrap analysis. All sites were treated as unordered 
and unweighted, and gaps treated as missing data. Diaporthe eres (JQ807445), D. helianthi (AJ312365), and D. ambigua (AY485744) were used as outgroups. TreeGraph 2 (Stöver et al. 2010) was used to refine the phylogenetic tree.

\section{Results}

\section{Taxonomy}

Kiliophora ubiensis Khutub. \& Nawawi

Fig. 1a-d

Colonies on the decaying leaves, scattered, mostly solitary, rarely in groups. Mycelium immersed in the substratum, 2-4 $\mu \mathrm{m}$ wide. Conidiophores macronematous, mononematous, dark brown, becoming paler toward the rounded apex, simple, erect, thick-walled, setiform, septate, up to $210 \mu \mathrm{m}$ long, $5.5-7 \mu \mathrm{m}$ wide. Conidiogenous cells formed from about the middle part of conidiophores through minute pores, enteroblastic, polytretic, discrete, hyaline, globose to

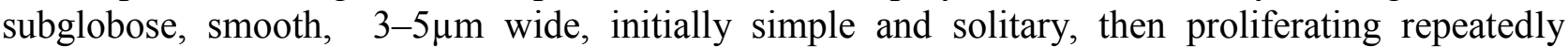
through one or more of the conidiogenous loci in the previously cell to generate branched chains of conidiogenous cells. Conidia $7-17 \times 2-4 \mu \mathrm{m}$, biconic, fusiform, aseptate, hyaline to subhyaline, smooth, solitary. Colonies on PDA (Potato Dextrose Agar) $\pm 4 \mathrm{~cm}$ after 14 days, dark-brown, thick, smooth with slightly irregular margin, covered with slim white mycelium, reverse black, no sporulation found.

Teleomorph - unknown.

Known distribution - Southeast Asia (Indonesia, Malaysia), Africa (Ivory Coast).

Material examined - Indonesia, West Java, Bogor, Situ Gede village, CIFOR forest area, on decaying leaf of Shorea sp., September 2012, Israwati Harahap, BO22692 (monoconidial isolate IPBCC 131080) (GenBank accession number: KF056850).

Notes - the morphological differences of $K$. fusispora and K. ubiensis were elucidated in detail by Khutubutheen \& Nawawi (1993), supported by precise line drawings and microphotographs. The current specimen found in Indonesia apparently resembles $K$. ubiensis due to its conidiogenous cells consistently proliferating repeatedly through one or more of the conidiogenous loci in the previously formed cell to produce branched chains of conidiogenous cells (observation from about 30 individual fruiting bodies) (Fig. 1). In K. fusispora, the proliferation of conidiogenous cells occurs occasionally (Kuthubutheen \& Nawawi 1993). Another morphological characters resemble $K$. ubiensis includes narrower setiform conidiophores $(210 \times 5.5-7 \mu \mathrm{m}$ vs. 200 $\times 6-9 \mu \mathrm{m}$ of $K$. fusispora), and smaller conidia $(7-17 \times 2-4 \mu \mathrm{m}$ vs. 30-37 $\times 6-8 \mu \mathrm{m}$ of $K$. fusispora $)$ (Kuthubutheen \& Nawawi 1993).

\section{Phylogenetic analyses}

Alignment of the ITS region contained 100 sequences and 736 total characters, of which 207 characters are constant, 122 characters are variable and parsimony-uninformative, 407 characters are parsimony-informative. From a total 525 of equally parsimonious trees generated by the MP analysis, the best parsimonious tree was generated in 3313 steps $(\mathrm{CI}=0.326, \mathrm{RI}=0.598$, $\mathrm{RC}=0.195, \mathrm{HI}=0.674)$. The phylogenetic tree confirmed the placement of $K$. ubiensis within family Amphisphaeriaceae. The sequence of $K$. ubiensis showed a close phylogenetic relationship to Polyscytalum fecundissimum (EU035441) and Phlogicylindrium spp. [Ph. eucalypti (DQ923534), Ph. eucalyptorum (EU040223), Ph. eucalyptorum (EU040222), Ph. uniforme (JQ044426)] with 54\% BS (Fig. 2).

\section{Discussion}

In the original publication of the genus Kiliophora, Khutubutheen \& Nawawi (1993) did not mention any information regarding its taxonomic position. At the moment, Kiliophora is noted as hypomycetous fungus anamorphic of Pezizomycotina due to lack of information of teleomorphic state (Kirk et al. 2008). Our BLAST result of $K$. ubiensis ITS sequence showed highest similarity to 


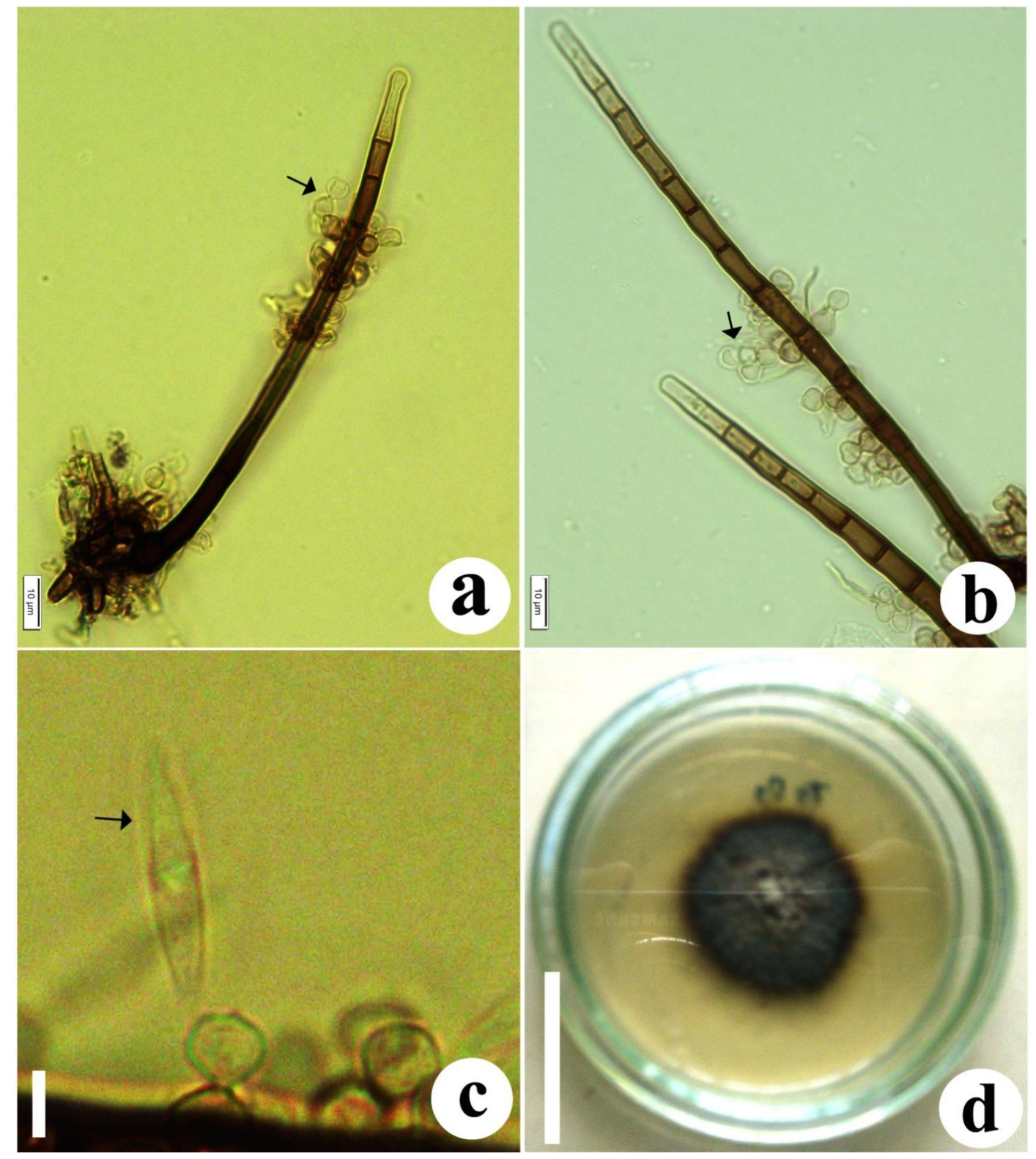

Fig. 1 - a-d Kiliophora ubiensis. a Proliferating conidiogenous cells (arrow). b Branched proliferation of conidiogenous cells (arrow). c Conidium (arrow). d 14-days old colony on PDA. Bars $\mathrm{c}=4 \mu \mathrm{m}, \mathrm{d}=40 \mathrm{~mm}$.

sequences belonging to Phlogicylindrium spp., Beltrania spp., Beltraniella portoricensis (GU905993), and Polyscytalum fecundissimum (EU035441) with only 89-90\% similarity (data not shown). These genera have been known as anamorphic of Amphisphaeriaceae. Among them, only genus Phlogicylindrium belongs to coelomycetous fungus (Crous et al. 2007). Based on the BLAST result, we constructed preliminary phylogenetic analyses involving large number sequences of taxa belong to Pezizomycotina. The analyses showed that Kiliophora nested in the Ordo Xylariales (data not shown). This information was further used to construct molecular phylogenetic analyses involving members of Xylariales. The phylogenetic trees clearly showed that sequence of $K$. ubiensis nested within the members of Amphisphaeriaceae (Fig. 2). However, the sequence of $K$. ubiensis showed no distinct association to recognized teleomorphic genera within Xylariales. 


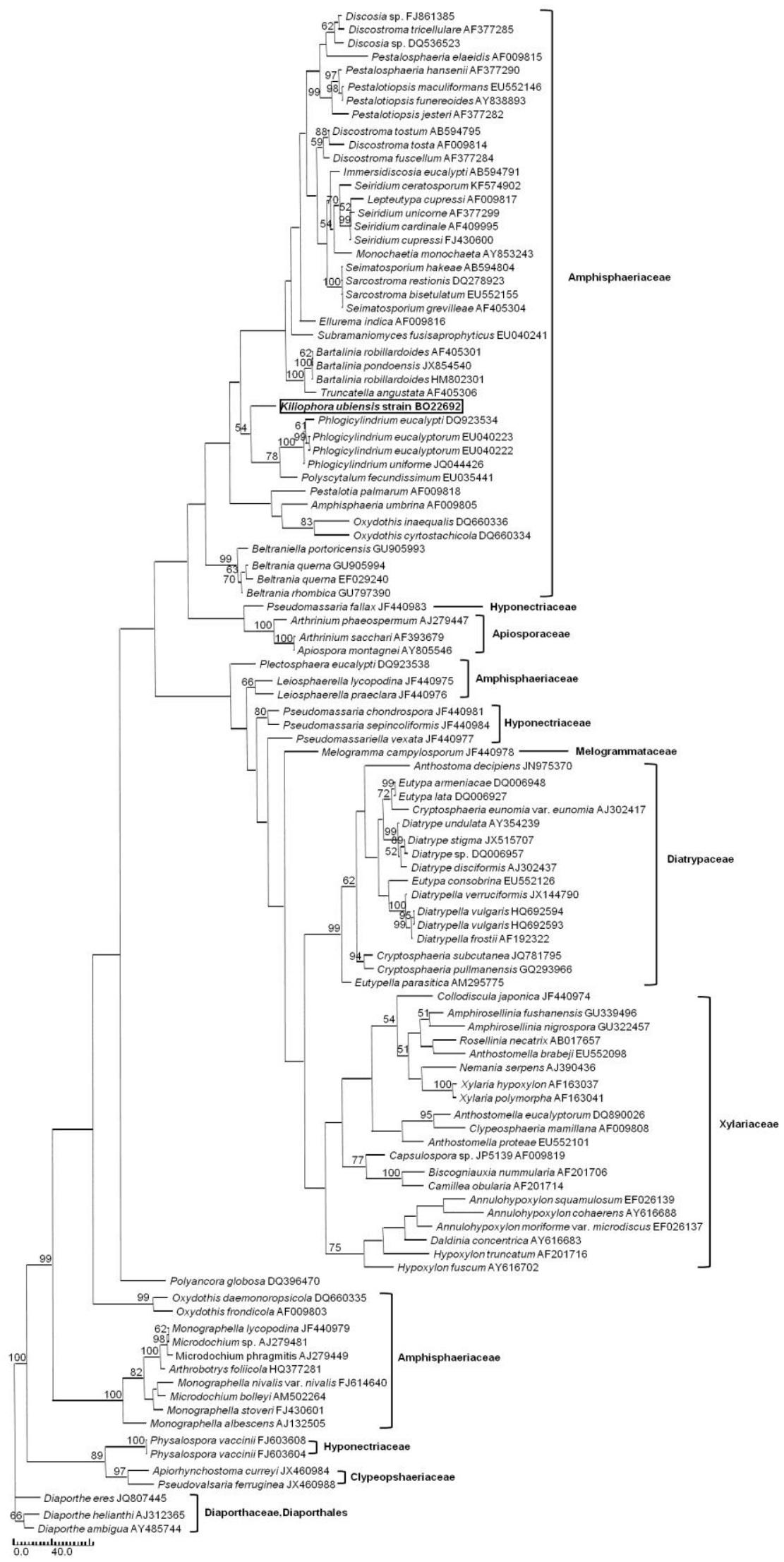

Fig. 2 - Phylogenetic tree generated from Maximum Parsimony (MP) analyses of the ITS rDNA involving 107 sequences from the ordo Xylariales including outgroups. Family placement of the sequences were referred to Lumbsch \& Huhndorf (2007), Kirk et al. (2008), Tanaka et al. (2011), and Jaklitsch \& Voglmayr (2012). Percentage bootstrap support ( $\geq 50 \%)$ is shown on the branches. 
The tree generated from ITS region showed a close phylogenetic affinity of $K$. ubiensis to the members of Phlogicylindrium and Polyscytalum (Fig. 2). However, Phlogicylindrium spp. are morphologically distinct from $K$. ubiensis by having conidiomata, cylindrical-hyaline conidia, and not denticulate conidiogenous cells. The setae in Phlogicylindrium spp. is also absent. Members of Phlogicylindrium have been known as foliar plant pathogens (Summerell et al. 2006, Crous et al. 2007, 2011), while the members of Kiliophora have been known as saprobes on decayed wood (Khutubutheen \& Nawawi 1993). Another phylogenetically close taxon, P. fecundissimum, is morphologically similar to $\mathrm{K}$. ubiensis due to having sympodial-denticulate conidiogenous cells, but differs to $K$. ubiensis due to lacking of setae and conidia formed in acropetal chains (Ellis 1971).

Four hyphomycetous genera-Beltrania Penz., Beltraniella Subram., Beltraniopsis Bat. \& J.L. Bezerra, and Subramaniomyces Varghese \& V.G. Rao-were morphologically found comparable to Kiliophora (Seifert et al. 2011). Morphological characteristics of dark and sterile setae, with denticulus conidiogenus cells that formed from the conidiophores, and biconic conidia of Beltrania, Beltraniella, and Beltraniopsis clearly resemble the genus Kiliophora (Seifert et al. 2011). However, these beltranioid fungi are morphologically distinct from Kiliophora by having brown conidia with hyaline equatorial band. The genus Subramaniomyces is similar to Kiliophora by having denticulus conidiogenus cells and biconic conidia, but differs due to lacking of setae and having basal ramoconidia (Seifert et al. 2011). In our phylogenetic analyses, K. ubiensis was found paraphyletic to the sequences of S. fusisaprophyticus (Matsush.) P.M. Kirk (EU040241), Beltraniella portoricensis (GU905993), and Beltrania spp. within family Amphisphaeriaceae (Fig. 2). Shirouzu et al. (2010) previously also reported the placement of the beltranioid fungi-Beltrania, Beltraniella, Beltraniopsis-and S. fusisaprophyticus within family Amphisphaeriacaeae (Xylariales), and noted that Beltraniella is linked to Pseudomasssaria Jacz. (Shirouzu et al. 2010, Hyde et al. 2011). All of these hyphomycetous genera having denticles conidiogenous cells that formed from the conidiophores.

According to Seifert et al. (2011), another hyphomycetous genera such as Chaetopsina Rambelli, Chaetopsis Grev., Zanclospora S. Hughes \& W.B. Kendr., and Spondylocladiopsis M.B. Ellis are also morphologically similar to Kiliophora by having setiform conidiophores, conidiogenous cells formed from the conidiophores, and amero, hyaline conidia. However, Kiliophora is distinguishable from Chaetopsina, Chaetopsis, Zanclospora, and Spondylocladiopsis due to its denticle and non-phialide condiogenous cells and biconic conidia with minute polar extensions. Currently, Chaetopsina and Zanclospora are placed in Nectriaceae (Hypocreales) (Luo \& Zhuang 2010) and Chaetosphaeriaceae (Chaetosphaeriales) (Fernández et al. 2006), respectively, based on morphology and molecular phyogenetic analyses of ribosomal DNA. The taxonomical status of Chaetopsis and Spondylocladiopsis have been noted as incertae sedis in fungal taxonomy (Hyde et al. 2011).

\section{Acknowledgements}

This research was supported by BOPTN DIPA IPB research grant (no 160/IT3.41.2/SPK/BOP/2013) awarded to Dr. Gayuh Rahayu. The authors also thank Floretta F. Yuliarni for laboratory assistance.

\section{References}

Choi YW, Hyde KD, Ho WH. 1999 - Single spore isolation of fungi. Fungal Diversity 3, 29-38.

Crous PW, Groenewald JZ, Smith IW. 2007 - Phlogicylindrium eucalyptorum. Fungal Planet 20.

Crous PW, Summerell BA, Shivas RG, Romberg M, Mel'nik VA, Verkley GJM, Groenewald JZ. 2011 - Fungal Planet Description Sheets: 92-106. Persoonia 27, 130-162.

Edgar RC. 2004 - MUSCLE: multiple sequence alignment with high accuracy and high throughput. Nucleic Acid Research 32, 1792-1797. http://dx.doi.org/10.1093/nar/gkh340 
Ellis MB. 1971 -Dematiaceous Hyphomycetes. CAB International Mycological Institute, 507 pp. Kew, UK.

Fernández FA, Miller AN, Huhndorf SM, Lutzoni FM, Zoller S. 2006 - Systematics of the genus Chaetosphaeria and its allied genera: morphological and phylogenetic diversity in north temperate and neotropical taxa. Mycologia 98, 122-123. http://dx.doi.org/10.3852/mycologia.98.1.121

Felsenstein J. 1985 - Confidence limits on phylogenies: an approach using the bootstrap. Evolution 39, 783-791.

Hyde KD, McKenzie EHC, KoKo TW. 2011 - Towards incorporating anamorphic fungi in a natural classification - checklist and notes for 2010. Mycosphere 2, 1-88.

Jaklitsch WM, Voglmayr H. 2012 - Phylogenetic relationships of five genera of Xylariales and Rosasphaeria gen. nov. (Hypocreales) Fungal Diversity 52, 75-98. http://dx.doi.org/10.1007/s13225-011-0104-2

Kirk PM, Cannon PF, Minter DW, Stalpers JA. 2008 - Ainsworth and Bisby's dictionary of the Fungi, 10th ed. CAB International, 2283pp. Wallingford, UK.

Kishino H, Hasegawa M. 1989 - Evaluation of the maximum likelihood estimate of the evolutionary tree topologies from DNA sequence data, and the branching order in Hominoidea. Journal of Molecular Evolution 29, 170-179.

Kuthubutheen AJ, Nawawi A. 1993 - Kiliophora: A new genus name for the hyphomycete taxon Danaea. Mycotaxon 48, 239-247.

Lumbsch HT, Huhndorf SM. 2007 - Outline of Ascomycota - 2007. Myconet 13, 1-58.

Luo J, Zhuang WY. 2010 - Chaetopsinectria (Nectriaceae, Hypocreales), a new genus Chaetopsina anamorphs. Mycologia 102, 976-984. http://dx.doi.org/10.3852/09-263

Seifert KA, Morgan-Jones GA, Gams W, Kendrick B. 2011 - The genera of hyphomycetes. CBS biodiversity series 9. CBS Fungal Diversity Centre 997pp. Utrecht, The Netherlands.

Shirouzu T, Hirose D, Tokumasu S, To-Anun C, Maekawa N. 2010 - Host affinity and phylogenetic position of a new anamorphic fungus Beltraniella botryospora from living and fallen leaves of evergreen oaks. Fungal Diversity 43, 85-92. http://dx.doi.org/10.1007/s13225-010-0037-1

Stöver BC, Müller KF. 2010 - TreeGraph 2: Combining and visualizing evidence from different phylogenetic analyses. BMC Bioinformatics 11, 7. http://dx.doi.org/10.1186/1471-2105-117

Summerell BA, Groenewald JZ, Carnegie AJ, Summerbell RC, Crous PW. 2006 - Eucalyptus microfungi known from culture. 2. Alysidiella, Fusculina and Phlogicylindrium genera nova, with notes on some other poorly known taxa. Fungal Diversity 23, 323-350.

Swofford DL. 2002 - PAUP*: Phylogenetic analyses using parsimony (* and other methods), version 4.0b 10. Sinauer Associates, Sunderland, Massachusetts.

Tamura K, Stecher G, Peterson D, Filipski A, Kumar S. 2013 - MEGA6: Molecular Evolutionary Genetics Analysis Version 6.0. Molecular Biology and Evolution 30, 2725-2729. http://dx.doi.org/10.1093/molbev/mst197

Tanaka K, Endo M, Hirayama K, Okane I, Hosoya T, Sato T. 2011 - Phylogeny of Discosia and Seimatosporium, and introduction of Adisciso and Immersidiscosia genera nova. Persoonia 26, 85-98. http://dx.doi.org/10.3767/003158511X576666

White TJ, Bruns T, Lee S, Taylor J. 1990 - Amplification and direct sequencing of fungal ribosomal RNA genes for phylogenetics. 315-322, in MA Innis et al. (eds.), PCR Protocols: a guide to methods and applications. San Diego, Academic Press. 